\title{
Synthesis and Spectral Properties of 6'-Triazolyl-Dihydroxanthene-Hemicyanine Fused Near-Infrared Dyes $\dagger$
}

\author{
Gu Lingyue, ${ }^{a}$ Kevin Renault, ${ }^{b}$ Anthony Romieu, ${ }^{* b}$ Jean-Alexandre Richard*c and Rajavel Srinivasan*a
}

We describe the synthesis of a range of 6'-triazolyl-dihydroxanthene-hemicyanine (DHX-hemicyanine) fused dyes through an effective copper-catalyzed azidealkyne cycloaddition (CUAAC) "click" reaction, with the dual aim of providing molecular diversity and fine tuning spectral properties of these near-infrared (NIR)-active materials. This was implemented by reacting 16 different aliphatic and aromatic azides with a terminal alkynyl-based-DHX-hemicyanine hybrid scaffold prepared in four steps and 35\% overall yield from 4-bromosalicylaldehyde. The resulting triazole derivatives have been fully characterized and their optical properties determined both in organic solvents and simulated physiological conditions (phosphate buffered saline containing $5 \%$ of bovine serum albumin protein). This systematic study is a first important step towards the development of NIR-I fluorogenic "click-on" dyes or related photoactive agents for light-based diagnostic and/or therapeutic applications.

\section{Introduction}

The essence of "click chemistry" reactions lies in their simplicity, speed and robustness even in aqueous media. ${ }^{1}$ While the concept has found popularity in organic chemistry, material science $^{2}$ and drug discovery, ${ }^{3}$ it comes as no surprise that biologists have also embraced it to perform chemistry in living systems (known as in vivo chemistry). ${ }^{4}$ By doing so, a new field coined biorthogonal chemistry emerged and aims at developing advanced chemistry tools for the rational modification of biomolecules helping to a better understand of biology. ${ }^{5}$ Of particular interest is the labelling of biomolecules monitoring their activity and leading to the discovery and/or deciphering of new biological mechanisms. In this context, the association of reactions belonging to the repertoire of "click chemistry" with organic-based fluorophores has propulsed the field of bioorthogonal chemistry to an indispensable tool for the optical imaging of biological systems. ${ }^{6}$ For instance, Meldal, ${ }^{7}$ Sharpless and co-workers $^{8}$ rejuvenated the Huisgen 1,3-cycloaddition ${ }^{9}$ and reported a regioselective $\mathrm{Cu}$-catalyzed version (known as CUAAC for copper-catalyzed azide-alkyne cycloaddition) which has become the most iconic "click" reaction known so far. ${ }^{10}$ Wang and co-workers applied it to fluorescent molecules and reported CUAAC reaction between 3-azidocoumarins and acetylenes. ${ }^{11}$ While the aryl azide precursor did not display any fluorescence properties, the study showed that some of the triazoles formed turned fluorescent. In a similar fashion, Bertozzi's group used an azido aryl moiety as C9-substituent of xanthene-based fluorophores. ${ }^{12}$ The initial azido rosamine did not emit any light because of a photoinduced electron transfer (PeT)-mediated quenching process. However, after evaluation of different positions of the azido group and electronic density of the aromatic ring, the fluorescence of the resulting triazole could be enhanced up to 58-fold (Scheme 1A). ${ }^{13}$ Kele's group also used aryl azide precursors ${ }^{14}$ but the approach using these scaffolds as fluorogenic precursors is limited because of their relative light instability and propensity to form the corresponding nitrene. It is possible to take advantage of this mechanism in the design of photoreactive cross-linkers suitable for photoaffinity labeling ${ }^{15}$ but in the context of the development of fluorogenic probes that instability is a serious limitation. ${ }^{16}$ One way around the need for an aryl azide precursor is to use a more stable terminal alkynyl-containing fluorophore, which, when the carbon-carbon triple bond replaces electron-donating groups (typically, $N, N$-dialkylamino moieties) it can turn the fluorophore to weakly or not fluorescent. This strategy was demonstrated by Tung's group on benzothiazoles ${ }^{17}$ and by Yao and co-workers on rosamine- and xanthone-based fluorophores which displayed an increase of fluorescence emission upon formation of the triazole ring (Scheme 1B). ${ }^{18}$ Despite the advantages of longer-wavelength fluorescence light, known to facilitate molecular imaging in complex biological systems, ${ }^{19}$ such strategies have mostly been implemented with fluorophores emitting in the visible spectral range and little progress has been made so far on the development of similar near-infrared (NIR)-emitting dyes (specifically, within NIR-I optical window 650-900 nm). Over the years, our respective groups have designed some chemistry leading to the development of a novel class of NIR-I dyes based on a molecular hybrid scaffold that combine both structural features of xanthene and cyanine parent compounds. These dihydroxanthene (DHX)-hemicyanine fused fluorophores are now regarded as attractive alternatives to the popular and commonly used polymethine-cyanine dyes, as illustrated by numerous and valuable achievements in the fields of biosensing, bioimaging and theranostics. ${ }^{20}$ Attracted by the modularity and ease of chemical modification of DHXhemicyanine hybrid dyes, ${ }^{21}$ we set out to develop the access to a DHX precursor allowing the facile "click" formation of triazoles. In a first attempt toward this goal, the introduction of an azido group on the $6^{\prime}$-position of the $\mathrm{DHX}$ skeleton proved to be a dead-end because of the marked photosensitivity of the aryl azide obtained. Instead, we took inspiration from our previous work to prepare an alkynyl-based DHX precursor 1 from the corresponding aryl bromide, explored CUAAC reaction with aliphatic and aromatic azides and determined the spectral 
properties of the resulting "click" fluorophores $\mathbf{2 a - 2} \mathbf{p}$ to assess the influence of both triazole moiety and its substitution pattern on NIR absorption/emission ability. (Scheme 1B). ${ }^{22}$ Details of these investigations and their possible extensions are discussed in the present Article.

A) Fluorogenic CUAAC reaction of aryl azides - Examples of coumarins and Si-rosamines

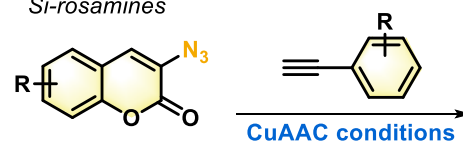<smiles>[R]c1cccc(-c2cn(-c3cc4ccccc4oc3=O)nn2)c1</smiles>

(I)

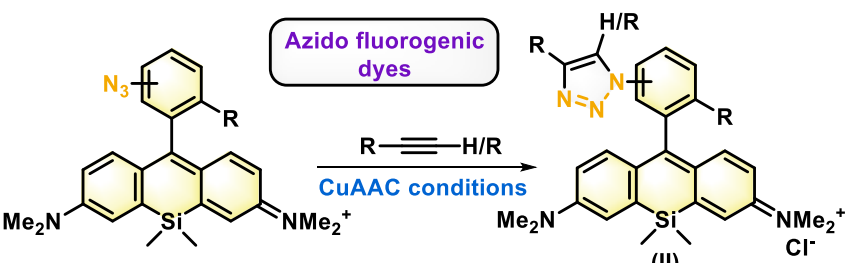

(II)

B) Fluorogenic CUAAC reaction of alkynyl-based chromophores - Examples of xanthones and DHX-hemicyanine hybrids
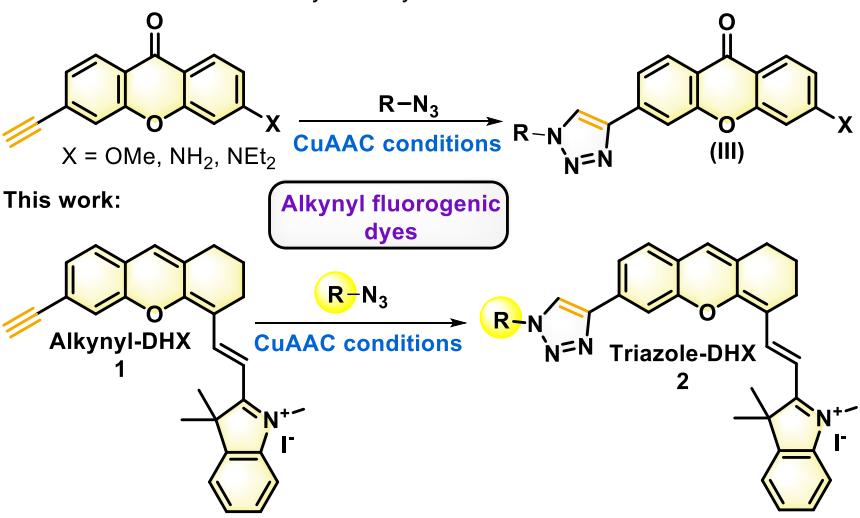

Scheme 1 CuAAC reaction for the development of fluorogenic "click-on" dyes. A) Reaction of 3-azidocoumarin and Si-rosamine fluorogenic dyes with terminal alkynes; B) Reaction of alkynyl-based xanthone and DHX fluorogenic dyes with azido compounds.

\section{Results and discussion}

Synthesis of a library of 6'-triazolyl-dihydroxanthene-hemicyanine fused dyes

We started our study with the preparation of the alkyne "click" partner 1 which we readily obtained in two steps from bifunctional arylbrominated aldehyde 6 (Scheme 2). This latter DHX-hemicyanine precursor was prepared in two steps from 3bromophenol 3 through (1) Casnati-Skatteb $\varnothing$ l ortho-formylation $\left(\mathrm{MgCl}_{2},(\mathrm{HCHO})_{n}, \mathrm{NEt}_{3}\right)^{23}$ that provided 4-bromosalicylaldehyde 4 in 69\% yield, and its subsequent (2) one-pot reaction with enal 5 to form the DHX skeleton $\mathbf{6}$. Its aryl bromide moiety was reacted with trimethylsilylacetylene $\mathbf{7}$ under Sonogashira reaction conditions $\left(\mathrm{Pd}\left(\mathrm{PPh}_{3}\right)_{4}, \mathrm{Cul}, 79 \%\right.$ yield). ${ }^{22}$ After removal of the TMS group under conventional conditions $\left(\mathrm{K}_{2} \mathrm{CO}_{3}\right.$, $\mathrm{CH}_{3} \mathrm{OH}$ ), the formyl group was reacted with 1,2,3,3-tetramethyl$3 \mathrm{H}$-indol-1-ium iodide (Fisher's base) $\mathbf{1 0}$ to yield the desired alkynyl-based DHX-hemicyanine fused dye 1 in $88 \%$ yield over two steps. The structure was proven by NMR and ESI mass analyses and the high level of purity $(>94 \%$ whatever the wavelength used for the UV-vis detection) was confirmed by RPHPLC-based analytical control (see ESI + ).

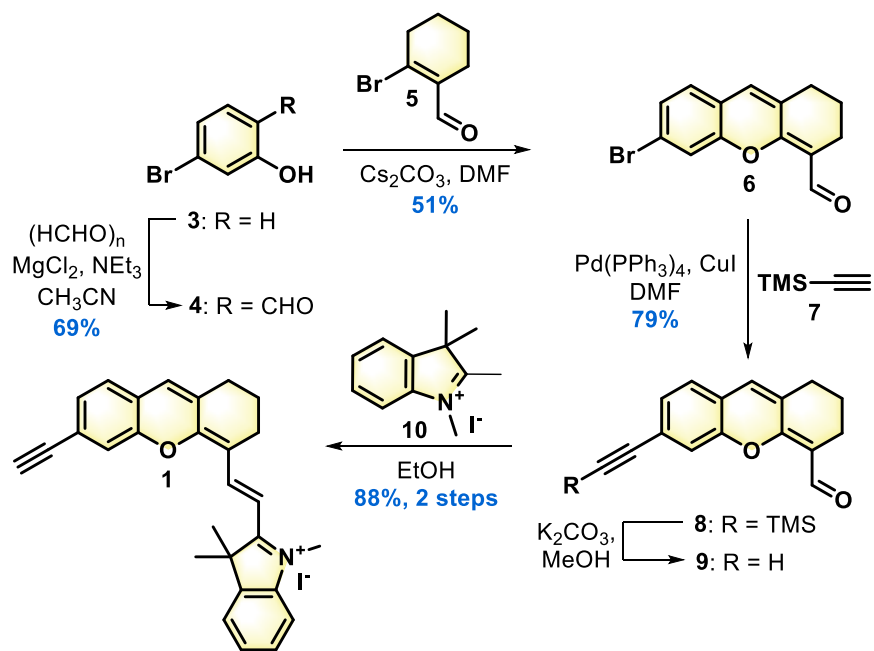

Scheme 2 Preparation of the alkynyl-based DHX-hemicyanine fused dye $\mathbf{1}$ in five steps from 3-bromophenol 3.

We next explored reaction conditions allowing the formation of the desired triazole ring at the 6 ' position of the DHX-hemicyanine fused dye (Scheme 3A). To this end, we optimized the reaction conditions at room temperature for 10 $\mathrm{h}$ in the presence of (3-azidopropyl)benzene 11a as azido "click" partner, sodium ascorbate and various copper sources. While the use of copper(II) chloride and copper(II) sulfate pentahydrate provided some product $(10 \%$ and $13 \%$ yield, respectively, Scheme 3A, entries 1-2), copper(II) acetate, copper(II) triflate and copper(I) chloride were much less successful (Scheme 3A, entries 3-6). Other usual "click" conditions using copper(I) sources without sodium ascorbate didn't provide any promising result either (Scheme 3A, entries 6 and 9). However, switching from the commonly used tertbutanol/water mixture of solvent to pure water in the presence of sodium ascorbate improved the yield significantly from $13 \%$ to $38 \%$ (Scheme 3A, entries 2 and 7). Ultimately, a mixture of DCM and water appeared to be optimal and with an interesting $50 \%$ yield (Scheme $3 \mathrm{~A}$, entry 8 ) it allowed us to explore the scope of the reaction with a wide range of alkyl and aryl azides 11b-p (see ESIt for their synthesis). 
A) Screening of reaction conditions for CUAAC

\begin{tabular}{|c|c|c|c|c|c|}
\hline Entry & Solvent & Catalyst & Additive & Time (h) & Yield $(\%)^{[\mathrm{a}]}$ \\
\hline 1 & $\mathrm{DCM} / \mathrm{H}_{2} \mathrm{O}(1: 1)$ & $\mathrm{CuCl}_{2}$ & $\mathrm{Na}$ ascorbate & 10 & 10 \\
\hline 2 & $\mathrm{tBuOH} / \mathrm{H}_{2} \mathrm{O}$ & $\mathrm{CuSO}_{4} \cdot 5 \mathrm{H}_{2} \mathrm{O}$ & $\mathrm{Na}$ ascorbate & 10 & 13 \\
\hline 3 & THF & $\mathrm{Cu}(\mathrm{OAc})_{2}$ & $\mathrm{Na}$ ascorbate & 10 & 0 \\
\hline 4 & THF & $\mathrm{Cu}(\mathrm{OTf})_{2}$ & $\mathrm{Na}$ ascorbate & 10 & Trace \\
\hline 5 & $\mathrm{EtOH}$ & $\mathrm{Cu}(\mathrm{OTf})_{2}$ & $\mathrm{Na}$ ascorbate & 10 & Trace \\
\hline 6 & $\mathrm{CH}_{3} \mathrm{CN}$ & $\mathrm{CuCl}$ & $\mathrm{NEt}_{3}$ & 10 & 0 \\
\hline 7 & $\mathrm{H}_{2} \mathrm{O}$ & $\mathrm{CuSO}_{4} \cdot 5 \mathrm{H}_{2} \mathrm{O}$ & $\mathrm{Na}$ ascorbate & 10 & 38 \\
\hline 8 & $\mathrm{DCM} / \mathrm{H}_{2} \mathrm{O}(1: 1)$ & $\mathrm{CuSO}_{4} \cdot 5 \mathrm{H}_{2} \mathrm{O}$ & $\mathrm{Na}$ ascorbate & 10 & 50 \\
\hline 9 & $\mathrm{DCM} / \mathrm{H}_{2} \mathrm{O}(1: 1)$ & Cul & $\mathrm{NEt}_{3}$ & 10 & 0 \\
\hline
\end{tabular}

[a] Isolated yield after purification by column chromatography over silica gel B) Scope of the synthesis of triazole-based DHX-hemicyanine hybrids

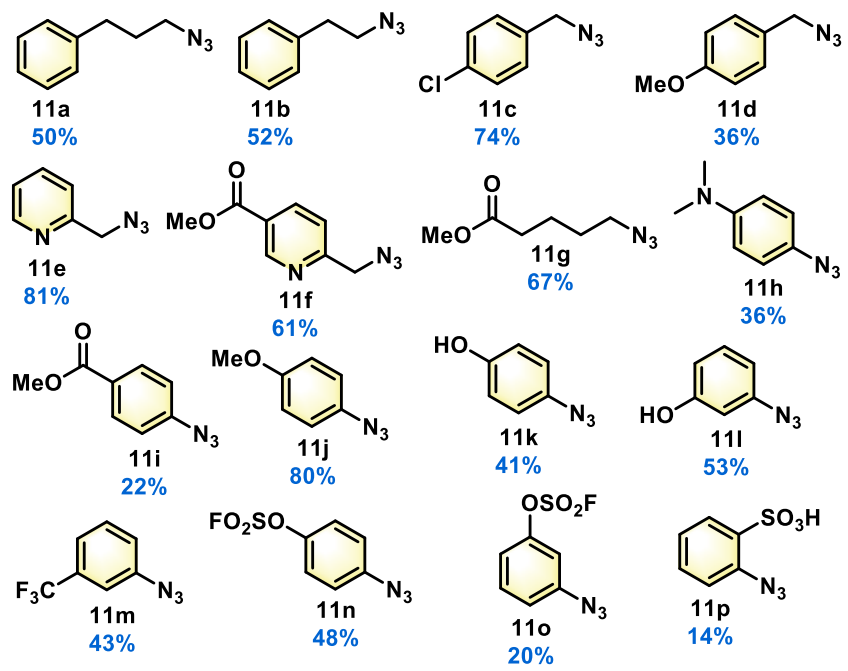

Scheme 3 A) Optimization of the CUAAC reaction for the synthesis of 6'-triazolyl-DHXhemicyanine fused dyes 2 ; B) Scope of the CuAAC reaction using aliphatic and aromatic azides.

With one less carbon in its alkyl chain, (2-azidoethyl)benzene 11b behaved similarly to azide 11a and formed the corresponding triazole $\mathbf{2 b}$ in $52 \%$ yield. 4-Chloro- and 4methoxybenzyl azide 11c and 11d were also successful (the corresponding triazoles $\mathbf{2 c}$ and $\mathbf{2} \mathbf{d}$ were isolated in $\mathbf{7 4 \%}$ and $36 \%$ yields, respectively) and the two 2-(azidomethyl)pyridines $11 \mathrm{e}$ and $11 \mathrm{f}$ developed by the Ting group to speed-up the CuAAC reaction in cellulo gave triazole cycloadducts $\mathbf{2 e}$ and $\mathbf{2 f}$ in good $81 \%$ and $61 \%$ yields, respectively. ${ }^{24}$ Since the availability of triazole-based fluorophores bearing an extra functional group for structural tuning or covalent conjugation to other (bio)molecular partners, is of great interest for considering valuable applications, CuAAC reaction was achieved with $\mathbf{1 1 g}$, 11i, 11n and 110 to introduce either a latent carboxylic acid (masked as methyl ester) or an aryloxysulfonyl fluoride moiety (this latter one being identified as an effective reactive partner in "click" reaction sulfur(VI) fluoride exchange (SuFEx) ${ }^{25}$ ). The possible influence of an electron-donating or -withdrawing substituent introduced on triazole moiety, over spectral properties of the resulting "clicked" DHX-based dyes, was also addressed through the successful synthesis of $2 \mathbf{h}$ and $\mathbf{2 j - 2 m}$. Finally, the presence of an ortho-substituted sulfonic acid group in 11p provided a simple way to introduce a polar group facilitating the water-solubilization of the resulting DHXhemicyanine fused dye $\mathbf{2 p}$ (Scheme 3B). The structures of these 16 novel triazole-based DHX-hemicyanine fused dyes were unambiguously confirmed by ESI-HRMS and NMR spectroscopic analyses (see ESIT). Their purity was checked by RP-HPLC and found to be above $95 \%$, value usually required to achieve relevant photophysical measurements.

\section{Photophysical properties of 6'-triazolyl-dihydroxanthene- hemicyanine fused dyes}

To assess changes in photophysical properties after triazole formation, we next studied the spectral behavior of our library of 16 DHX-hemicaynine fused dyes $\mathbf{2 a - 2 p}$ and alkynyl precursor $\mathbf{1}$ in different media including phosphate buffered saline (PBS) with $5 \%$ $(\mathrm{w} / \mathrm{v})$ bovine serum albumin (BSA) as simulated body fluid, EtOH, and $\mathrm{CHCl}_{3}$ (Table 1 and Fig. 1 for the Abs/Ex/Em spectra of 1 and $\mathbf{2 p}$ in $\mathrm{CHCl}_{3}$ and in $\mathrm{PBS}+5 \% \mathrm{BSA}$, see ESIt for Abs/Ex/Em spectra of other compounds). A first general trend common to all triazole-based dyes and alkyne 1 is the dramatic broadening of the main absorption band assigned to $\mathrm{S}_{0}-\mathrm{S}_{1}$ electronic transition, compared to that of more conventional DHX-hemicyanine fused fluorophore bearing a $\mathrm{N}, \mathrm{N}$ dialkylamino group as C-6' substituent. Thus, a full-width half maximum (FWHM), $\Delta \lambda_{1 / 2}$ max in the range of $115-155 \mathrm{~nm}$ is observed depending primarily on the solvent used, against only $36-51 \mathrm{~nm}$ for 12. Unlike the latter, well-defined vibronic structures with two maxima and one pronounced blue-shifted shoulder are observed in all absorption spectra. The lack of an effective electron-donating group such as $-\mathrm{NEt}_{2}$, on $\mathrm{C}^{-} \mathrm{C}^{\prime}$ position, induces an expected hypsochromic shift of ca. $50 \mathrm{~nm}$ or $100 \mathrm{~nm}$ depending the local absorption maximum regarded for the triazole derivatives, of the maximum absorption peak position for the DHX-hemicyanine hybrid scaffold.

Red excitation at $620 \mathrm{~nm}$ produced the desired NIR emission in the form of a vibronic structure with two well-defined maxima in the range $690-760 \mathrm{~nm}$. However, only a very weak fluorescence emission intensity was observed, whatever the triazole derivative studied, the solvent and concentration range (1-10 $\mu \mathrm{M})$ used. It prevented us to accurately determine relative fluorescence quantum yields, roughly estimated at less than $1 \%$. The very low values of these quantum yields cannot be attributed to the formation of non-emissive aggregates (i.e., $\mathrm{H}$-type homodimers) ${ }^{26}$ because a good matching between the absorption and excitation spectra was observed except for some triazole derivatives and 1 in PBS + 5\% BSA. However, in 

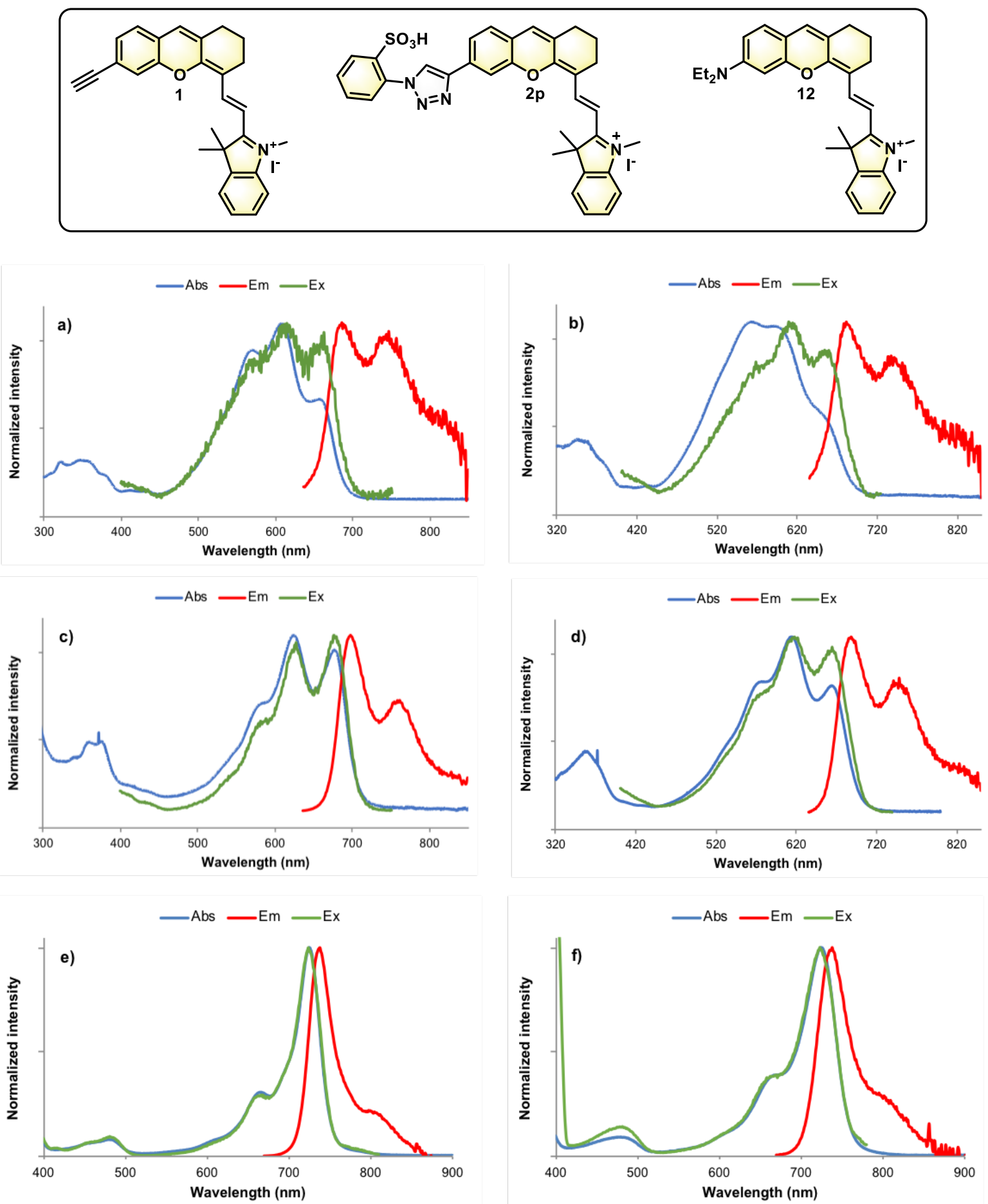

Fig. 1 Normalised absorption, emission (excitation at $620 \mathrm{~nm}$ for a-d and $650 \mathrm{~nm}$ for e-f) and excitation (emission at $760 \mathrm{~nm}$ for a-d, $830 \mathrm{~nm}$ for e or $800 \mathrm{~nm}$ for $\mathrm{f}$ ) spectra of alkynylbased DHX-hemicyanine fused dye 1 ( $a$ in $\mathrm{CHCl}_{3}$ and b in PBS + 5\% BSA), triazole-based DHX-hemicyanine fused dye $2 \mathrm{p}$ ( $\mathrm{c}$ in $\mathrm{CHCl}_{3}$ and d in PBS + 5\% BSA), and $\mathrm{N}, \mathrm{N}$-diethylaminoDHX-hemicyanine fused dye 12 (e in $\mathrm{CHCl}_{3}$ and $\mathrm{f}$ in PBS $+5 \% \mathrm{BSA}$ ). For the excitation spectrum of $\mathbf{1 2}$ in PBS $+5 \%$ BSA, a peak at $400 \mathrm{~nm}\left(\lambda_{\mathrm{ex}} / 2\right.$ ) assigned to Rayleigh scattering is observed. See the Experimental section for details about these measurements.

order to assess the ability of DHX-hemicyanine fused dye $\mathbf{1}$ to act as an effective alkynyl partner in "click-on" fluorogenic reactions, we have nevertheless calculated the ratio [(integration of emission curve)/absorption at $620 \mathrm{~nm}$ )] for a $5 \mu \mathrm{M}$ solution in $\mathrm{CHCl}_{3}$ of each compound ( $\mathbf{1}$ and $\mathbf{2 a - 2 p}$ ), and we have found values in the range 1.06.2 for triazole derivatives compared to 0.6 for $\mathbf{1}$ (see ESI + ). Thus, a 10 -fold increase in fluorescence signal should be obtained for CUAAC reaction between 1 and 2-azidobenzenesulfonic acid 11p, the azido "click" partner leading to the most fluorescent triazole-based DHXhemicyanine fused dye $\mathbf{2 p}$ (ratio $=6.2$ ), together with a change in color of solution from sapphire blue to sky blue (see ESI†).

\section{Conclusions}

Quest for high-performance NIR-I fluorophores based on the attractive DHX-hemicyanine hybrid scaffold led us to consider 
for the first time CUAAC "click" reaction as a simple and effective way of achieving high molecular diversity through the straightforward synthesis of alkynyl-based DHX-hemicyanine fused dye 1 and its "click" derivatisation with a wide range of organic azides. In contrast to already published fluorogenic alkynes photoactive only in the blue-green spectral range, a modest but encouraging "turn-on" response upon "click" reaction was obtained within the NIR-I window. Thus, our efforts that involved both synthesis and comprehensive photophysical characterization of a library of 16 different compounds, have enabled us to identify a promising candidate $2 p$ which deserved a further structural optimization to obtain a NIR-I fluorogenic "click-on" dye suitable for bioimaging. Interestingly, the specific molecular absorption signature of both alkyne and triazole derivatives (i.e., broad, structured and weakly solvent dependent absorption band) could be used to rapidly design novel broad spectrum dark quencher molecules suitable for the construction of far-red or NIR-I fluorescence light-up probes based on Förster resonance energy transfer (FRET) mechanism. ${ }^{27}$ The third and final aspect relates to the possible valorization of poorly fluorescent "click"-convertible alkynyl-based DHX-hemicyanine dye $\mathbf{1}$ as a valuable molecular precursor to practical photosensitizers (i.e., PDT agents) ${ }^{28}$ and/or photothermal agents ${ }^{29}$ for therapeutic purposes. In this context, its ability to generate reactive oxygen species (ROS such as singlet oxygen) upon illumination will be further investigated by us.

\section{Experimental $\uparrow$}

See ESIt for the details about sections "General", "Instruments and methods", and all experimental and spectral data associated with synthesised compounds.

\section{Synthesis}

\section{6-((Trimethylsilyl)ethynyl)-2,3-dihydro-1H-xanthene-4}

carbaldehyde (8). $\mathrm{Pd}\left(\mathrm{PPh}_{3}\right)_{4}(67.5 \mathrm{mg}, 8.3 \mathrm{mmol} \%)$ and $\mathrm{Cul}(23.6 \mathrm{mg}$, $0.1 \mathrm{mmol}$ ) were degassed in a flame-dried round bottom flask. $\mathrm{NEt}_{3}$ $(1.2 \mathrm{~mL}, 8.3 \mathrm{mmol})$ in dry DMF $(10 \mathrm{~mL})$ was added with aryl bromide $6(1.2 \mathrm{~g}, 4.1 \mathrm{mmol})$. The solution was degassed again then trimethylsilylacetylene 7 was added $(1.8 \mathrm{~mL}, 12.4 \mathrm{mmol})$. The reaction mixture was heated to $85^{\circ} \mathrm{C}$ for $24 \mathrm{~h}$. After being cooled to room temperature, the reaction mixture was concentrated under vacuum and the resulting residue was purified by flash-column chromatography on silica gel (eluent: $1 \%$ EtOAc in PE) affording pure TMS-protected terminal alkyne 8 as a orange solid (1.0 g, yield 79\%). ${ }^{1} \mathrm{H}$ NMR $\left(400 \mathrm{MHz}, \mathrm{CDCl}_{3}\right): \delta=10.30(\mathrm{~s}, 1 \mathrm{H}), 7.17(\mathrm{~s}, 1 \mathrm{H}), 7.13(\mathrm{dd}, J$ $=7.8 \mathrm{~Hz}, J=1.2 \mathrm{~Hz}, 1 \mathrm{H}), 7.05(\mathrm{~d}, J=7.8 \mathrm{~Hz}, 1 \mathrm{H}), 6.62(\mathrm{~s}, 1 \mathrm{H}), 2.58$ (ddd, $J=7.5 \mathrm{~Hz}, J=5.8 \mathrm{~Hz}, J=1.6 \mathrm{~Hz}, 2 \mathrm{H}$ ), $2.43(\mathrm{t}, J=6.0 \mathrm{~Hz}, 2 \mathrm{H}$ ), $1.71(\mathrm{~m}, 2 \mathrm{H}), 0.25(\mathrm{~s}, 9 \mathrm{H}) ;{ }^{13} \mathrm{C}$ NMR $\left(101 \mathrm{MHz}^{\mathrm{C}} \mathrm{CDCl}_{3}\right): \delta=188.0$, $159.9,151.7,130.8,127.6,126.5,126.1,124.6,121.6,118.6,113.8$, 104.0, 96.9, 30.3, 21.6, 20.4, 0.0 ppm; HRMS (ESI+): $\mathrm{m} / \mathrm{z} 331.1141$ [M $+\mathrm{Na}]^{+}$, calcd for $\mathrm{C}_{19} \mathrm{H}_{20} \mathrm{O}_{2} \mathrm{SiNa}^{+} 331.1125$.

6-Ethynyl-2,3-dihydro-1H-xanthene-4-carbaldehyde (9). TMSprotected terminal alkyne $8(1.0 \mathrm{~g}, 3.3 \mathrm{mmol})$ was dissolved in dry $\mathrm{MeOH}(30 \mathrm{~mL})$ and treated with anhydrous $\mathrm{K}_{2} \mathrm{CO}_{3}(1.8 \mathrm{~g}, 13.2 \mathrm{mmol})$.
The mixture was stirred at room temperature for $5 \mathrm{~h}$. The solvent was removed, and the residue was taken up in $100 \mathrm{~mL}$ of DCM and washed with $100 \mathrm{~mL}$ of deionised water. The organic layer was dried over anhydrous $\mathrm{Na}_{2} \mathrm{SO}_{4}$ and concentrated under reduced pressure. This compound was used in the next step without further purification, and the yield was assumed to be quantitative. ${ }^{1} \mathrm{H}$ NMR $\left(400 \mathrm{MHz}\right.$, DMSO- $\left.d_{6}\right): \delta=10.26(\mathrm{~s}, 1 \mathrm{H}), 7.36(\mathrm{~d}, J=7.9 \mathrm{~Hz}, 1 \mathrm{H}), 7.34$ $(\mathrm{s}, 1 \mathrm{H}), 7.24(\mathrm{dd}, J=7.8 \mathrm{~Hz}, J=1.5 \mathrm{~Hz}, 1 \mathrm{H}), 7.01(\mathrm{~s}, 1 \mathrm{H}), 4.37(\mathrm{~s}, 1 \mathrm{H})$, 2.59 (ddd, $J=7.0 \mathrm{~Hz}, J=5.3 \mathrm{~Hz}, J=1.6 \mathrm{~Hz}, 2 \mathrm{H}$ ), $2.30(\mathrm{t}, J=6.0 \mathrm{~Hz}, 2$ $\mathrm{H}), 1.63(\mathrm{~m}, 2 \mathrm{H}) \mathrm{ppm} ;{ }^{13} \mathrm{C} \mathrm{NMR}\left(101 \mathrm{MHz}, \mathrm{CDCl}_{3}\right): \delta=188.1,159.8$, $151.7,131.1,127.7,126.6,125.9,123.6,122.0,118.9,113.9,82.8$, 79.3, 30.3, 21.6, 20.4 ppm; HRMS (ESI+): $m / z 237.0910\left[\mathrm{M}+\mathrm{H}^{+}\right.$, calcd for $\mathrm{C}_{16} \mathrm{H}_{13} \mathrm{O}_{2}+237.0910$.

Alkynyl-based DHX-hemicyanine fused dye (1). To aldehyde 9 (236 $\mathrm{mg}, 1.0 \mathrm{mmol})$ in EtOH $(2 \mathrm{~mL})$ was added 1,2,3,3-tetramethyl-3Hindol-1-ium iodide $10(301 \mathrm{mg}, 1.0 \mathrm{mmol})$ and the solution was refluxed at $80^{\circ} \mathrm{C}$ for $4 \mathrm{~h}$. The reaction mixture was concentrated and the crude product was purified by flash-column chromatography on silica gel (eluent: $1 \% \mathrm{MeOH}$ in DCM) to afford alkynyl-DHX 1 as a dark blue solid (345 mg, yield $88 \%) .{ }^{1} \mathrm{H}$ NMR (400 MHz, DMSO- $\left.d_{6}\right): \delta=8.56$ (d, $J=15.3 \mathrm{~Hz}, 1 \mathrm{H}), 7.80-7.73(\mathrm{~m}, 2 \mathrm{H}), 7.62(\mathrm{~s}, 1 \mathrm{H}), 7.58(\mathrm{~m}, 1 \mathrm{H})$, $7.52(\mathrm{~m}, 2 \mathrm{H}), 7.39-7.33(\mathrm{~m}, 2 \mathrm{H}), 6.68(\mathrm{~d}, J=15.4 \mathrm{~Hz}, 1 \mathrm{H}), 4.52(\mathrm{~s}, 1$ H), $3.95(\mathrm{~s}, 3 \mathrm{H}), 2.72(\mathrm{t}, J=6.0 \mathrm{~Hz}, 2 \mathrm{H}), 2.67(\mathrm{t}, J=6.0 \mathrm{~Hz}, 2 \mathrm{H}), 1.83$ $(\mathrm{m}, 2 \mathrm{H}), 1.77(\mathrm{~s}, 6 \mathrm{H}) \mathrm{ppm} ;{ }^{13} \mathrm{C} \mathrm{NMR}\left(101 \mathrm{MHz}\right.$, DMSO- $\left.d_{6}\right): \delta=179.0$, 158.0, 151.8, 145.1, 142.4, 142.1, 131.1, 129.8, 128.8, 128.4, 127.8, $127.6,123.8,122.6,122.2,118.6,114.3,113.8,107.2,83.8,82.6$, 50.8, 33.2, 28.7, 26.9, 23.5, 19.7 ppm; HRMS (ESI+): $m / z 392.2019$ [M] ${ }^{+\bullet}$, calcd for $\mathrm{C}_{28} \mathrm{H}_{26} \mathrm{NO}^{+} 392.2009$; $\mathrm{HPLC}$ (system A): $t_{\mathrm{R}}=4.9 \mathrm{~min}$ (purity $94 \%$ at $260 \mathrm{~nm}$ and $98 \%$ at $600 \mathrm{~nm}$ ); LRMS (ESI+, recorded during RP-HPLC analysis): $m / z 392.3[\mathrm{M}]^{+\bullet}(100)$, calcd for $\mathrm{C}_{28} \mathrm{H}_{26} \mathrm{NO}^{+}$ 392.2; UV-vis (recorded during the HPLC analysis): $\lambda_{\max }=559$ and 592 $\mathrm{nm}$ (broad band).

General procedure for the synthesis of tetrazole-based DHX-

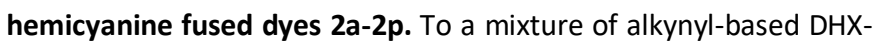
hemicyanine dye 1 (784 mg, $2.0 \mathrm{mmol}, 1.0$ equiv.) and the corresponding organic azide 11a-p (2.6 mmol, 1.3 equiv.) in deionised water and $\mathrm{CH}_{2} \mathrm{Cl}_{2}(1: 1(\mathrm{v} / \mathrm{v}), 100 \mathrm{~mL})$, sodium ascorbate ( $79.2 \mathrm{mg}, 0.4 \mathrm{mmol}, 0.2$ equiv.) was added, followed by the addition of $\mathrm{CuSO}_{4} \cdot 5 \mathrm{H}_{2} \mathrm{O}(25 \mathrm{mg}, 0.1 \mathrm{mmol}, 0.05$ equiv.). The heterogeneous mixture was stirred vigorously at room temperature overnight. Thereafter, the reaction mixture was concentrated under reduced pressure and directly purified by flash-column chromatography on silica gel (eluent: $1 \% \mathrm{MeOH}$ in DCM) to afford the corresponding triazole $\mathbf{2 a - 2 p}$ as a dark blue amorphous powder.

\section{Photophysical characterisations}

UV-visible spectra were obtained either on a Varian Cary 50 scan (single-beam) or an Agilent technologies 60 (single-beam) spectrophotometer (software Cary WinUV) by using rectangular quartz cells (Hellma, 100-QS, $45 \times 12.5 \times 12.5 \mathrm{~mm}$, pathlength: $10 \mathrm{~mm}$, chamber volume: $3.5 \mathrm{~mL}$ ), at $25^{\circ} \mathrm{C}$ (using a temperature control system combined with water circulation). Fluorescence spectra (emission/excitation spectra) were recorded with an HORIBA Jobin Yvon Fluorolog spectrofluorometer (FluorEssence software) at $25{ }^{\circ} \mathrm{C}$ (using a temperature control system 
combined with water circulation), with standard fluorometer cells (Labbox, LB Q, light path: $10 \mathrm{~mm}$, width: $10 \mathrm{~mm}$, chamber volume: $3.5 \mathrm{~mL}$ ). The absorption and fluorescence emission spectra were recorded with dye solutions of concentrations in the range of $10^{-5}-10^{-6} \mathrm{M}$. The emission spectra were recorded in the range of $635-850 \mathrm{~nm}$ after excitation at $620 \mathrm{~nm}$ (shutter: Auto Open, integration time $=0.1 \mathrm{~s}, 1 \mathrm{~nm}$ step, $\mathrm{HV}(\mathrm{S} 1)=950 \mathrm{~V}$, excitation slit $=5 \mathrm{~nm}$ and emission slit $=5 \mathrm{~nm}$ ). The excitation spectra were recorded in the range of 400-750 nm after emission at $760 \mathrm{~nm}$ (excitation slit $=5 \mathrm{~nm}$ for spectra recorded in $\mathrm{CHCl}_{3}$ and $12 \mathrm{~nm}$ for spectra recorded in $\mathrm{EtOH}$ or PBS $+5 \%$ $\mathrm{BSA}$ and emission slit $=5 \mathrm{~nm}$ ). All excitation/emission spectra are corrected.

\section{Conflicts of interest}

The authors declare no conflict of interest.

\section{Acknowledgements}

This work is supported by SPST, Tianjin University (P.R. China), ICES, A*STAR (Singapore), and the CNRS, Universite de Bourgogne and Conseil Régional de Bourgogne through the "Plan d'Actions Régional pour I'Innovation (PARI) and the "Fonds Européen de Développement Régional (FEDER)" programs. Financial supports from Agence Nationale de la Recherche (ANR, AAPG 2018, PRCI LuminoManufacOligo, ANR-18-CE07-0045-01), especially for the post-doc fellowship of K. R., the National Research Foundation Singapore (NRF, LuminoManufacOligo, NRF2018-NRF-ANR035) and GDR CNRS "Agents d'Imagerie Moléculaire" (AIM) 2037 are also greatly acknowledged. The authors thank Ms Doris Tan (ICES, Singapore) for the recording of HRMS spectra. A. R. and K. R thank the "Plateforme d'Analyse Chimique et de Synthèse Moléculaire de l'Université de Bourgogne" (PACSMUB, http://www.wpcm.fr) for access to spectroscopy instrumentation.

\section{Notes and references}

1 H. C. Kolb, M. G. Finn and K. B. Sharpless, Angew. Chem. Int. Ed., 2001, 40, 2004.

2 (a) J.-F. Lutz, Angew. Chem. Int. Ed., 2007, 46, 1018; (b) H. Nandivada, X. Jiang and J. Lahann, Adv. Mater., 2007, 19, 2197.

3 H. C. Kolb and K. B. Sharpless, Drug Discov. Today, 2003, 8, 1128.

4 (a) J. A. Prescher and C. R. Bertozzi, Nat. Chem. Biol., 2005, 1, 13; (b) M. Boyce and C. R. Bertozzi, Nat. Methods, 2011, 8, 638; (c) C. R. Bertozzi and P. Wu, Curr. Opin. Chem. Biol., 2013, 17, 717; (d) J. G. Rebelein and T. R. Ward, Curr. Opin. Biotechnol., 2018, 53, 106.

5 (a) J. M. Baskin and C. R. Bertozzi, QSAR \& Comb. Sci., 2007, 26, 1211; (b) E. M. Sletten and C. R. Bertozzi, Angew. Chem. Int. Ed., 2009, 48, 6974; (c) E. M. Sletten and C. R. Bertozzi, Acc. Chem. Res., 2011, 44, 666.

6 (a) C. Le Droumaguet, C. Wang and Q. Wang, Chem. Soc. Rev., 2010, 39, 1233; (b) P. Shieh and C. R. Bertozzi, Org. Biomol. Chem., 2014, 12, 9307.

7 (a) C. W. Tornøe, C. Christensen and M. Meldal, J. Org. Chem., 2002, 67, 3057; (b) M. Meldal and C. W. Tornøe, Chem. Rev., 2008, 108, 2952.

8 V. V. Rostovtsev, L. G. Green, V. V. Fokin and K. B. Sharpless, Angew. Chem. Int. Ed., 2002, 41, 2596.

9 R. Huisgen, Proc. Chem. Soc., 1961, 357.
10 D. Brunel and F. Dumur, New J. Chem., 2020, 44, 3546.

11 K. Sivakumar, F. Xie, B. M. Cash, S. Long, H. N. Barnhill and Q. Wang, Org. Lett., 2004, 6, 4603.

12 (a) P. Shieh, M. J. Hangauer and C. R. Bertozzi, J. Am. Chem. Soc., 2012, 134, 17428; (b) P. Shieh, V. T. Dien, B. J. Beahm, J. M. Castellano, T. Wyss-Coray and C. R. Bertozzi, J. Am. Chem. Soc., 2015, 137, 7145.

13 P. Shieh, M. S. Siegrist, A. J. Cullen and C. R. Bertozzi, Proc. Natl. Acad. Sci. U S A, 2014, 111, 5456.

14 (a) A. Herner, I. Nikić, M. Kállay, E. A. Lemke and P. Kele, Org. Biomol. Chem., 2013, 11, 3297; (b) G. B. Cserép, A. Herner and P. Kele, Methods Appl. Fluoresc. , 2015, 3, 042001; (c) Z. Pünkösti, P. Kele and A. Herner, J. Het. Chem., 2018, 55, 1183.

15 G. T. Hermanson, in Bioconjugate Techniques (Third Edition), Academic Press, Boston, 2013, ch. 3, pp. 253.

16 E. Păunescu, L. Louise, L. Jean, A. Romieu and P.-Y. Renard, Dyes Pigm., 2011, 91, 427.

17 (a) J. Qi and C.-H. Tung, Bioorg. Med. Chem. Lett., 2011, 21, 320; (b) J. Qi, M.-S. Han, Y.-C. Chang and C.-H. Tung, Bioconjugate Chem., 2011, 22, 1758.

18 J. Li, M. Hu and S. Q. Yao, Org. Lett., 2009, 11, 3008.

19 (a) R. Weissleder and U. Mahmood, Radiology, 2001, 219, 316; (b)

J. V. Frangioni, Curr. Opin. Chem. Biol., 2003, 7, 626; (c) I. Martinić,

S. V. Eliseeva and S. Petoud, J. Lumin., 2017, 189, 19.

20 H. Chen, B. Dong, Y. Tang and W. Lin, Acc. Chem. Res., 2017, 50, 1410.

21 (a) J.-A. Richard, Org. Biomol. Chem., 2015, 13, 8169; (b) A. Romieu and J.-A. Richard, Tetrahedron Lett., 2016, 57, 317; (c) M. J. H. Ong, S. Debieu, M. Moreau, A. Romieu and J.-A. Richard, Chem. Asian J., 2017, 12, 936; (d) S. Zheng, G. Lingyue, M. J. H. Ong, D. Jacquemin, A. Romieu, J.-A. Richard and R. Srinivasan, Org. Biomol. Chem., 2019, 17, 4291.

22 M. J. H. Ong, R. Srinivasan, A. Romieu and J.-A. Richard, Org. Lett., 2016, 18, 5122.

23 (a) N. U. Hofsløkken and L. Skattebøl, Acta Chem. Scand., 1999, 53, 258; (b) T. V. Hansen and L. Skattebøl, Org. Synth., 2005, 82, 64; (c) T. V. Hansen and L. Skattebøl, Org. Synth., 2012, 89, 220.

24 C. Uttamapinant, A. Tangpeerachaikul, S. Grecian, S. Clarke, U. Singh, P. Slade, K. R. Gee and A. Y. Ting, Angew. Chem. Int. Ed., 2012, 51, 5852.

25 (a) J. Dong, L. Krasnova, M. G. Finn and K. B. Sharpless, Angew. Chem. Int. Ed., 2014, 53, 9430; (b) A. S. Barrow, C. J. Smedley, Q. Zheng, S. Li, J. Dong and J. E. Moses, Chem. Soc. Rev., 2019, 48, 4731; (c) A. Marra, C. Nativi and A. Dondoni, New J. Chem., 2020, 44, 4678.

26 M. Ogawa, N. Kosaka, P. L. Choyke and H. Kobayashi, ACS Chem. Biol., 2009, 4, 535.

27 (a) T. Myochin, K. Hanaoka, S. Iwaki, T. Ueno, T. Komatsu, T. Terai, T. Nagano and Y. Urano, J. Am. Chem. Soc., 2015, 137, 4759; (b) J. Demuth, R. Kucera, K. Kopecky, Z. Havlínová, A. Libra, V. Novakova, M. Miletin and P. Zimcik, Chem. Eur. J., 2018, 24, 9658.

28 (a) H.-W. Liu, X.-X. Hu, K. Li, Y. Liu, Q. Rong, L. Zhu, L. Yuan, F.-L. Qu, X.-B. Zhang and W. Tan, Chem. Sci., 2017, 8, 7689; (b) F. Xu, H. Li, Q. Yao, H. Ge, J. Fan, W. Sun, J. Wang and X. Peng, Chem. Sci., 2019, 10, 10586.

29 H. S. Jung, P. Verwilst, A. Sharma, J. Shin, J. L. Sessler and J. S. Kim, Chem. Soc. Rev., 2018, 47, 2280. 
Table 1 Photophysical properties of alkynyl-based DHX-hemicyanine fused dye 1 and triazole derivatives $2 \mathrm{a}-\mathbf{2} \mathbf{k}$ and $\mathbf{2 m - 2 p}$ at $25^{\circ} \mathrm{C}$. For structures, see ESI†.

\begin{tabular}{|c|c|c|c|c|c|c|c|c|c|c|c|c|c|}
\hline \multirow{2}{*}{ Entry } & \multirow{2}{*}{ Dye } & \multicolumn{3}{|c|}{ Abs $\max ^{a}[\mathrm{~nm}]$} & \multicolumn{3}{|c|}{$\mathrm{Em} \mathrm{max}^{c, d}[\mathrm{~nm}]$} & \multicolumn{3}{|c|}{$\varepsilon\left[\mathrm{M}^{-1} \mathrm{~cm}^{-1}\right]$} & \multicolumn{3}{|c|}{ Stokes' shift $^{e}\left[\mathrm{~cm}^{-1}\right]$} \\
\hline & & $\mathrm{CHCl}_{3}$ & $\mathrm{EtOH}$ & $\mathrm{PBS}^{b}$ & $\mathrm{CHCl}_{3}$ & $\mathrm{EtOH}$ & PBS & $\mathrm{CHCl}_{3}$ & $\mathrm{EtOH}$ & PBS & $\mathrm{CHCl}_{3}$ & $\mathrm{EtOH}$ & PBS \\
\hline \multirow{3}{*}{1} & \multirow{3}{*}{1} & 569 & 562 & 566 & \multirow{3}{*}{$\begin{array}{l}685 \\
746\end{array}$} & \multirow{3}{*}{$\begin{array}{l}675 \\
728\end{array}$} & \multirow{3}{*}{$\begin{array}{l}681 \\
741\end{array}$} & 25700 & 38750 & 31150 & \multirow{3}{*}{1876} & \multirow{3}{*}{1935} & \multirow{3}{*}{2038} \\
\hline & & 607 & 597 & 598 & & & & 45200 & 42200 & 31000 & & & \\
\hline & & 654 & 640 & 645 & & & & 38300 & 22850 & 16700 & & & \\
\hline \multirow{3}{*}{2} & \multirow{3}{*}{$2 a$} & 579 & 572 & 578 & \multirow{3}{*}{$\begin{array}{l}693 \\
755\end{array}$} & \multirow{3}{*}{$\begin{array}{l}686 \\
741\end{array}$} & \multirow{3}{*}{$\begin{array}{l}688 \\
751\end{array}$} & 34200 & 35200 & 28600 & \multirow{3}{*}{1777} & \multirow{3}{*}{1870} & \multirow{3}{*}{1752} \\
\hline & & 617 & 608 & 614 & & & & 52050 & 44200 & 34550 & & & \\
\hline & & 670 & 656 & 662 & & & & 40600 & 28200 & 22500 & & & \\
\hline \multirow{3}{*}{3} & \multirow{3}{*}{$2 b$} & 579 & 573 & 575 & \multirow{3}{*}{$\begin{array}{l}691 \\
755\end{array}$} & \multirow{3}{*}{$\begin{array}{l}685 \\
742\end{array}$} & \multirow{3}{*}{$\begin{array}{l}687 \\
748\end{array}$} & 41800 & 42100 & 35700 & \multirow{3}{*}{1683} & & \\
\hline & & 619 & 608 & 612 & & & & 63500 & 53100 & 41250 & & 1849 & 1784 \\
\hline & & 671 & 656 & 661 & & & & 48600 & 33700 & 26450 & & & \\
\hline & & 579 & 571 & 573 & & & & 38100 & 45100 & 36700 & & & \\
\hline 4 & $2 c$ & 618 & 607 & 612 & 692 & 684 & 688 & 58900 & 56450 & 39300 & 1730 & 1854 & 1805 \\
\hline & & 670 & 656 & 662 & 752 & 744 & & 45800 & 35500 & 25300 & & & \\
\hline & & 579 & 571 & 573 & & & & 40400 & 44250 & 38500 & & & \\
\hline 5 & $2 d$ & 618 & 608 & 611 & 693 & 685 & 686 & 59050 & 55850 & 41000 & 1751 & 1849 & 1789 \\
\hline & & 670 & 656 & 663 & 754 & 749 & 748 & 43500 & 35600 & 27050 & & & \\
\hline & & 580 & 572 & 570 & & & & 42100 & 43050 & 38950 & & & \\
\hline 6 & $2 e$ & 620 & 607 & 607 & 694 & 685 & 688 & 62200 & 54150 & 35700 & 1720 & 1876 & 1939 \\
\hline & & 671 & 656 & 661 & & & & 46100 & 34200 & 23350 & & & \\
\hline & & 580 & 571 & 576 & & & & 37200 & 35750 & 30500 & & & \\
\hline 7 & $2 f$ & 618 & 607 & 613 & 694 & 687 & 686 & 55300 & 44800 & 38700 & 1772 & 1918 & 1736 \\
\hline & & 669 & 656 & 662 & 758 & 743 & 749 & 41500 & 28250 & 27500 & & & \\
\hline & & 580 & 571 & 572 & & & & 37800 & 39350 & 33700 & & & \\
\hline 8 & $2 g$ & 620 & 607 & 610 & 694 & 686 & 686 & 58400 & 49600 & 35700 & 1720 & 1897 & 1816 \\
\hline & & 672 & 657 & 661 & 758 & 746 & 751 & 45500 & 31400 & 23750 & & & \\
\hline 0 & & 583 & 574 & 583 & 696 & 691 & 689 & 37300 & 41950 & 31900 & & & \\
\hline 9 & $2 \mathrm{~h}$ & 621 & 610 & 615 & 760 & 751 & 752 & 56400 & 52850 & 35450 & 1735 & 1921 & 1746 \\
\hline
\end{tabular}




\begin{tabular}{|c|c|c|c|c|c|c|c|c|c|c|c|c|c|}
\hline & & 674 & 658 & 671 & & & & 43800 & 33950 & 23500 & & & \\
\hline \multirow{4}{*}{10} & & 581 & 572 & 570 & 695 & & 689 & 37800 & 41500 & 33100 & & & \\
\hline & \multirow[t]{3}{*}{$2 i$} & 619 & 608 & 605 & \multirow{2}{*}{758} & $\begin{array}{l}685 \\
748\end{array}$ & \multirow{2}{*}{751} & 56700 & 51150 & 25650 & \multirow[t]{3}{*}{1766} & \multirow[t]{3}{*}{1849} & \multirow[t]{2}{*}{2015} \\
\hline & & 670 & 656 & 674 & & 748 & & 43700 & 31650 & 14100 & & & \\
\hline & & 580 & 572 & 577 & \multirow{3}{*}{$\begin{array}{l}697 \\
758\end{array}$} & \multirow{3}{*}{$\begin{array}{l}687 \\
749\end{array}$} & \multirow{3}{*}{$\begin{array}{l}691 \\
746\end{array}$} & 38700 & 44700 & 35300 & & & \\
\hline \multirow[t]{3}{*}{11} & \multirow[t]{3}{*}{$2 j$} & 620 & 608 & 612 & & & & 58600 & 56000 & 38700 & \multirow[t]{3}{*}{1782} & \multirow[t]{3}{*}{1891} & \multirow[t]{2}{*}{1868} \\
\hline & & 671 & 657 & 667 & & & & 45350 & 35350 & 25800 & & & \\
\hline & & 581 & 573 & 573 & \multirow{3}{*}{$\begin{array}{l}693 \\
757\end{array}$} & \multirow{3}{*}{$\begin{array}{l}687 \\
747\end{array}$} & \multirow{3}{*}{$\begin{array}{l}691 \\
749\end{array}$} & 37650 & 40600 & 19250 & & & \\
\hline \multirow[t]{3}{*}{12} & \multirow[t]{3}{*}{$2 k$} & 619 & 609 & 612 & & & & 57100 & 51000 & 20800 & \multirow[t]{2}{*}{1725} & \multirow[t]{2}{*}{1864} & \multirow[t]{2}{*}{1868} \\
\hline & & 671 & 658 & 656 & & & & 44150 & 32500 & 17400 & & & \\
\hline & & 581 & 571 & 573 & \multirow{3}{*}{$\begin{array}{l}694 \\
753\end{array}$} & \multirow{3}{*}{$\begin{array}{l}685 \\
742\end{array}$} & \multirow{3}{*}{$\begin{array}{l}690 \\
748\end{array}$} & 39100 & 43350 & 37050 & & & \\
\hline \multirow[t]{3}{*}{13} & \multirow[t]{3}{*}{$2 m$} & 619 & 606 & 610 & & & & 60100 & 53000 & 35250 & \multirow[t]{2}{*}{1746} & \multirow[t]{3}{*}{1903} & 1900 \\
\hline & & 671 & 655 & 665 & & & & 47300 & 32300 & 21950 & & & \\
\hline & & 579 & 571 & 573 & & & & 34550 & 39100 & 37900 & & & \\
\hline 14 & $2 n$ & 619 & 607 & 607 & $\begin{array}{l}690 \\
756\end{array}$ & $\begin{array}{l}683 \\
745\end{array}$ & $\begin{array}{l}691 \\
748\end{array}$ & 54400 & 47550 & 35250 & 1662 & 1833 & 2003 \\
\hline & & 672 & 655 & 662 & 156 & 145 & 148 & 43250 & 28900 & 21600 & & & \\
\hline & & 580 & 571 & 574 & & & & 36400 & 44600 & 36400 & & & \\
\hline 15 & 20 & 618 & 607 & 611 & $\begin{array}{l}093 \\
760\end{array}$ & $\begin{array}{l}081 \\
745\end{array}$ & $\begin{array}{l}092 \\
747\end{array}$ & 55100 & 54050 & 37000 & 1751 & 1790 & 1916 \\
\hline & & 670 & 655 & 655 & 100 & $14 J$ & 141 & 42750 & 32700 & 22900 & & & \\
\hline & & 585 & 573 & 577 & 697 & 684 & 688 & 25750 & 31250 & 24650 & & & \\
\hline 16 & $2 p$ & 624 & 610 & 613 & 761 & 747 & 749 & 43050 & 40600 & 32200 & 1678 & 1773 & 1778 \\
\hline & & 677 & 658 & 665 & 161 & 141 & 149 & 39200 & 27050 & 23050 & & & \\
\hline
\end{tabular}

